\title{
Chemical analysis of atmospheric aerosols
}

\author{
Urs Baltensperger • André S. H. Prévôt
}

Published online: 20 November 2007

(C) Springer-Verlag 2007

\section{Introduction}

An aerosol is an assembly of liquid or solid particles which are suspended in a gaseous medium long enough to enable observation and measurement. The atmospheric aerosol thus describes the system of particles suspended in our atmosphere. Generally, the sizes of aerosol particles are in the range 0.001-100 $\mu \mathrm{m}$. Sampled aerosol particles are also called particulate matter (PM). According to the cutoff used during sampling, a suffix is often used, thus, $\mathrm{PM}_{10}$ denotes all aerosol particles with an aerodynamic particle diameter $d \leq 10 \mu \mathrm{m}$. Most legal standards are related to $\mathrm{PM}_{10}$. Atmospheric aerosols are of interest mainly because of their effects on health and climate. Concerning health, many epidemiological studies have shown a link between increased mortality/morbidity and increased $\mathrm{PM}_{10}$ or $\mathrm{PM}_{2.5}$ (see [1] and references therein). Concerning climate, aerosol particles scatter and absorb light (known as the direct effect on climate), and modify cloud properties (with a variety of effects known as indirect effects) [2]. These effects are influenced by the chemical and physical properties of the aerosol particles, which makes these properties important to be measured. In addition, the chemical composition reveals information about the sources of the atmospheric aerosols. Thus, for optimal mitigation processes the chemical composition needs to be known.

Figure 1 presents the average chemical composition of $\mathrm{PM}_{10}$ from Zurich (data from [3]). Elemental carbon (EC), trace elements and mineral dust are so-called primary aerosol constituents, i.e., they are directly emitted into the

U. Baltensperger $(\bowtie) \cdot$ A. S. H. Prévôt

Laboratory of Atmospheric Chemistry, Paul Scherrer Institut (PSI), 5232 Villigen, Switzerland

e-mail: urs.baltensperger@psi.ch atmosphere in particulate form. On the other hand, nitrate and sulfate are only formed in the atmosphere through the oxidation of the gaseous species $\mathrm{NO}_{\mathrm{x}}$ (i.e., sum of $\mathrm{NO}$ and $\mathrm{NO}_{2}$ ) and $\mathrm{SO}_{2}$ to nitric and sulfuric acid and subsequent neutralization of ammonia. These components are thus called secondary. Organic matter (OM) is composed of organic carbon (OC), which includes a variety of heteroatoms such as oxygen, hydrogen, or nitrogen. A conversion factor is therefore used to calculate $\mathrm{OM}$ from the measured $\mathrm{OC}$ concentration. OM can be of primary or secondary origin. The sum of OM and EC is also called carbonaceous aerosol. The unknown fraction consists of a considerable amount of water [3].

While the sources of the inorganic constituents are quite well known, very little is still known about the chemical composition of OM. This paper therefore focuses on the chemical analysis of $\mathrm{OM}$, and includes a discussion of primary versus secondary and anthropogenic versus biogenic carbon.

\section{Carbonaceous aerosol}

A large number of individual compounds are present in OM: Hamilton et al. [4] isolated more than 10,000 different compounds from an aerosol sample by orthogonal gas chromatography $(\mathrm{GC} \times \mathrm{GC})$ coupled to a time of flight mass spectrometer (ToF-MS). However, only a small fraction of compounds was actually identified and quantified. As shown by the group of Glen Cass (Caltech, Pasadena) in the 1990 s, typically only about $20 \%$ of the total OM can be identified (e.g., see [5]). This is partly due to the recently discovered fact that organic compounds tend to oligomerize [6]. In this process, large molecules with molecular weight up to $1,000 \mathrm{Da}$ are formed, which may 
not be accessible to traditional analysis methods. Thus, new methods are needed, which are able to analyze these oligomers. Formation of these oligomers is suspected to be one of the major reasons for the fact that models typically yield lower organic aerosol mass concentrations than field measurements, both in urban and remote areas [7-9]. Johnson et al. [10] had to increase all partitioning coefficients between the gas and aerosol phase by a speciesindependent factor of 500, to bring results of simulations of total organic aerosol mass concentrations in agreement with field results. Smog chamber results will be important for the quantification of such partitioning coefficients. However, they need to be done at atmospheric concentrations, since experiments at high precursor concentrations result in high (atmospherically not relevant) organic aerosol mass concentrations, which drives semivolatile species into the aerosol phase, resulting in higher yields for the wrong reason [11].

\section{Chemical mass balance}

Cass and coworkers used chemical mass balance (CMB) analysis based on tracer substances from emission measurements to perform source apportionment studies at a variety of locations. These tracers included hopanes and steranes from petroleum use in motor vehicles; phytosterols, lignans, phenolic products from lignins, and diterpenoids from resins in wood smoke; cholesterol in meat charbroiling smoke; high-molecular-weight odd-carbon number $n$ alkanes in the particles shed as leaves rub together in the wind, and iso- and anteiso-alkanes in cigarette smoke [12].
This approach was highly successful, but it suffered from the weaknesses that the tracers had to be assumed to be inert, i.e., not susceptible to atmospheric degradation processes, and that only primary organic aerosol components could be identified. This approach is still being used, with a substantially extended list of tracers: Subramanian et al. [13] also considered the uncertainties associated with photochemical aging and were able to account for emissions from eight primary source classes, including major anthropogenic sources such as motor vehicles, cooking, and biomass combustion as well as some primary biogenic emissions (leaf abrasion products). However, secondary organic aerosol was still only indirectly accessible by this approach, assuming that the ambient $\mathrm{OC}$ that is not apportioned by the CMB model belongs to SOA.

Distinction of primary and secondary organic aerosol was also done based on the $\mathrm{EC} / \mathrm{OC}$ ratio, assuming that $\mathrm{OC}$ found in excess of the EC/OC ratio of relevant sources could be attributed to SOA [14]. This approach as well as the $\mathrm{CMB}$ approach tended to yield results where the primary organic aerosol (POA) dominated. Recent studies indicate that this approach often overestimates POA. Robinson et al. showed [15] that most primary organic particulate emissions are semivolatile. The fact that they partially evaporate with atmospheric dilution explains why the traditional $\mathrm{EC} / \mathrm{OC}$ ratio approach tended to overestimate the primary fraction. Robinson et al. further showed that photo-oxidation of this low-volatility gas-phase material from diesel emissions has a high SOA formation potential [15]. Taking these effects into account results in substantially higher SOA fractions and brings model predictions into better agreement with observations.

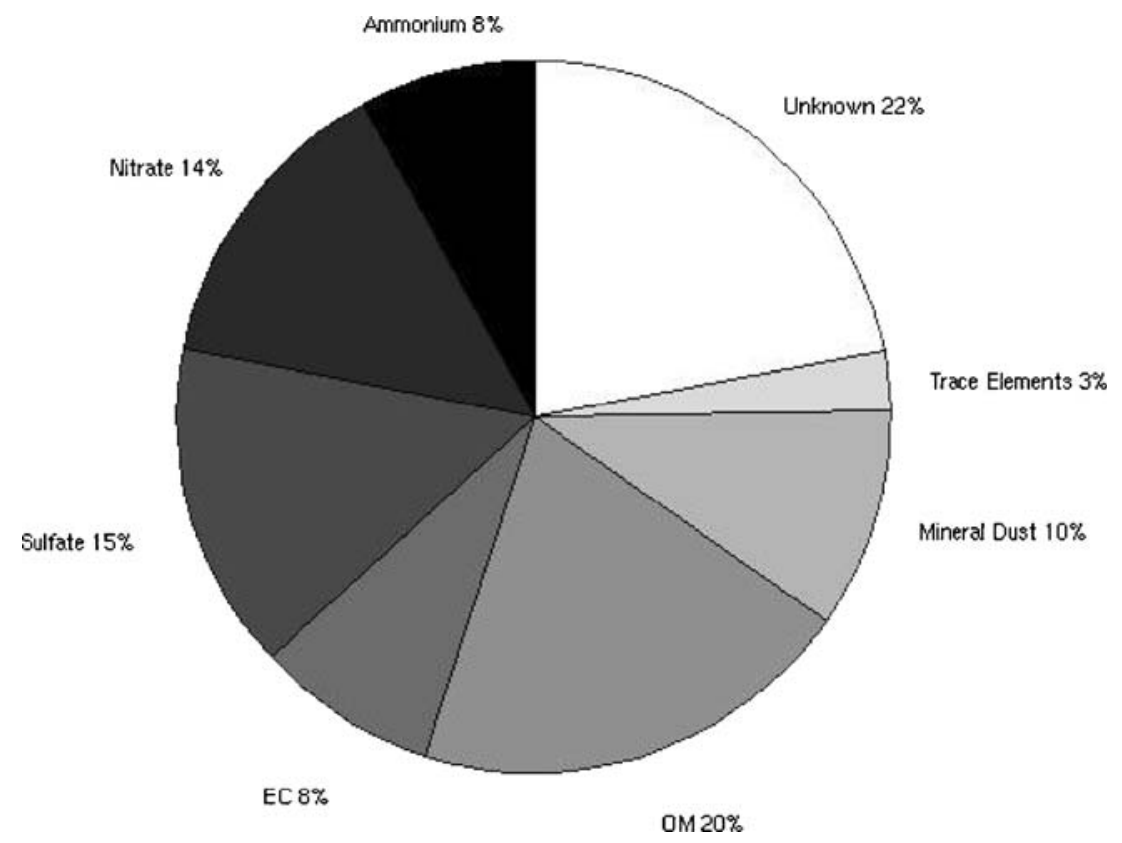

Fig. 1 Chemical composition of $\mathrm{PM}_{10}$ from Zurich, Switzerland (data from [3]) 


\section{The Aerodyne aerosol mass spectrometer}

Recently, many field observations have been obtained with measurements with the Aerodyne aerosol mass spectrometer (AMS). This instrument provides on-line, quantitative measurements of the total mass and size distributed nonrefractory chemical composition of the submicron ambient aerosol at a high temporal resolution [16]. Studies with this instrument suggest that SOA dominates OM levels, even in urban areas $[8,17,18]$. In most of these studies the AMS data were deconvolved into hydrocarbon-like OA (HOA) and several types of oxygenated OA (OOA) components using individual mass fragments or a combination thereof. HOA was linked to primary combustion emissions (mainly from fossil fuel) and other primary sources such as meat cooking, while OOA was mainly associated with SOA. Another potential source of OOA is the oxidation of POA. The fraction originating from this process is expected to be minor compared to the SOA; however, this remains to be elucidated.

A recent novel approach takes advantage of the full spectrum rather than individual mass fragments and uses positive matrix factorization (PMF) to identify the main components of the total organic aerosol and their sources [17]. As a result, several primary sources such as fossil fuel combustion, charbroiling, or wood burning were identified. Interestingly, this approach results in quite similar sources as the CMB approach of Cass and coworkers. However, in addition to the primary sources the secondary organic aerosol is now also accessible. Furthermore, the oxygenated organic aerosol could be separated into a highly aged fraction, OOA I, with low volatility and a mass spectrum similar to fulvic acid, and a more volatile and probably less processed fraction, OOA II. While the temporal evolution of OOA I has a high similarity to that of sulfate (which does not evaporate at enhanced ambient temperature and thus typically shows highest concentrations in the afternoon), the temporal evolution of OOA II resembles that of nitrate (which typically peaks during night times) [17]. Similar observations suggest that these findings may also apply to other sites, and it is to be expected that a number of further papers will deal with this aspect. A further development deals with hybrid receptor models which incorporate a priori known source composition [19]. Thus this approach is a hybrid of CMB (where the nature of the source profiles has to be known in advance) and PMF (where the non-negative composition of a given number of source profiles can be estimated without any a priori knowledge). In addition most of the field studies published so far were performed with the quadrupole version of the AMS. It is expected that the new development of the ToFAMS [20] will further enhance the possibilities of such analyses.

\section{Carbon-14 analysis}

While the AMS is highly promising in distinguishing the organic aerosol into primary and secondary components, its limitation should also be noted. First, as mentioned, the AMS only determines the non-refractory material. Thus, refractory components need to be addressed with other methods. In addition, it is still not possible to distinguish anthropogenic and biogenic SOA. Here, the combination with another powerful method - the carbon-14 analysis-is most promising. These radiocarbon measurements of the carbonaceous aerosol offer the opportunity of a direct distinction between fossil and non-fossil sources, e.g., particulate matter from wood burning and traffic [21]: due to its age ${ }^{14} \mathrm{C}$ has completely disintegrated in fossil substances, whereas modern plant material is on the contemporary radiocarbon level [22]. This intrinsic isotopic information characterizes the sources of ambient PM independent of its history in terms of emission conditions or atmospheric transport. Such carbon-14 measurements have been performed for quite some time, but only a discrimination of $\mathrm{OC}$ and EC prior to the carbon-14 determination reveals the full power of this method: EC is often dominated by fossil fuel, while OC typically has a higher biogenic fraction. These features are not accessible in a carbon-14 analysis of the total carbon [23].

\section{Terminology}

Primary and secondary aerosol constituents are not always used in a consistent manner, which often creates confusion. Therefore, here we provide a definition which hopefully avoids confusion. As mentioned above, primary aerosol constituents are directly emitted in particulate form. While this definition is clear, e.g., for EC, potential confusion arises for the nucleation mode that is often seen in traffic emissions. These particles do not contain soot, and form as a result of a decrease in temperature of the exhaust gas without modification of gaseous precursors by chemical reaction and not because of secondary atmospheric reactions, and therefore have to be regarded as primary aerosol [24]. As mentioned above, semivolatile primary constituents may partially evaporate when dilution results in a decrease of the total organic aerosol concentration [15]. Further potential confusion arises from POA that is oxidized in the atmosphere. Fuzzi et al. [25] suggested calling this fraction secondary. However, the major part of these oxidized molecules still contains the original information from their primary emission, e.g., their carbon-14 content still reflects their fossil or biogenic origin. Thus we suggest reserving the term secondary exclusively for aerosol constituents that enter the aerosol phase from the 
gas phase as a result of chemical transformation processes. Consequently, oxidized POA should be called aged primary organic aerosol, and not SOA.

\section{Outlook}

Clearly the instrumentation that has become available in recent years offers highly interesting new means for source apportionment of organic aerosols. Alternative recent developments in applying techniques like H-NMR, spectroscopy at various wavelengths including synchrotron radiation, and LC-MS should be further explored in combination with the methods discussed here. Overall, there is a large remaining dilemma: while carbon-14 analysis points to a large biogenic fraction of organic carbon and especially of its water-soluble fraction $[22,26]$, the latter appears to be highly correlated with anthropogenic tracers [26]. To solve this dilemma, methods to distinguish anthropogenic and biogenic SOA that allow for a higher time resolution than carbon-14 analysis would be highly beneficial.

Acknowledgment This work was supported by the Swiss National Science Foundation, the Swiss Federal Office for the Environment as well as the European Commission projects ACCENT, EUCAARI, EUROCHAMP, and POLYSOA.

\section{References}

1. Laden F, Schwartz J, Speizer FE, Dockery DW (2006) Am J Respir Crit Care Med 173:667-672

2. IPCC (2007) Cambridge University Press http://ipcc-wg1.ucar. edu/wg1/wg1-report.html

3. Hueglin C, Gehrig R, Baltensperger U, Gysel M, Monn C, Vonmont H (2005) Atmos Environ 39:637-651

4. Hamilton JF, Webb PJ, Lewis AC, Hopkins JR, Smith S, Davy P (2004) Atmos Chem Phys 4:1279-1290

5. Rogge WF, Mazurek MA, Hildemann LM, Cass GR, Simoneit BRT (1993) Atmos Environ 27A:1309-1330

6. Kalberer M, Paulsen D, Sax M, Steinbacher M, Dommen J, Prévôt ASH, Fisseha R, Weingartner E, Frankevich V, Zenobi R, Baltensperger U (2004) Science 303:1659-1662

7. Heald CL, Jacob DJ, Park RJ, Russell LM, Huebert BJ, Seinfeld JH, Liao H, Weber RJ (2005) Geophys Res Lett 32:L18809. DOI 10.1029/2005GL023831

8. Volkamer R, Jimenez JL, San Martini F, Dzepina K, Zhang Q, Salcedo D, Molina LT, Worsnop DR, Molina MJ (2006) Geophys Res Lett 33:L17811. DOI 10.1029/2006GL026899
9. de Gouw JA, Middlebrook AM, Warneke C, Goldan PD, Kuster WC, Roberts JM, Fehsenfeld FC, Worsnop DR, Canagaratna MR, Pszenny AAP, Keene WC, Marchewka M, Bertman SB, Bates TS (2005) J Geophys Res 110:D16305. DOI 10.1029/ 2004JD005623

10. Johnson D, Utembe SR, Jenkin ME, Derwent RG, Hayman GD, Alfarra MR, Coe H, McFiggans G (2006) Atmos Chem Phys $6: 403-418$

11. Duplissy J, Gysel M, Alfarra MR, Dommen J, Metzger A, Prevot ASH, Weingartner E, Laaksonen, Raatikainen T, Good N, Turner SF, McFiggans G, Baltensperger U (2007) The cloud forming potential of secondary organic aerosol under near atmospheric conditions. Geophys Res Lett (in press)

12. Cass GR (1998) Anal Chem 17:356-366

13. Subramanian R, Donahue NM, Bernardo-Bricker A, Rogge WF, Robinson AL (2007) Atmos Environ. DOI 10.1016/j.atmosenv

14. Lim HJ, Turpin BJ (2002) Environ Sci Technol 36:4489-4496

15. Robinson AL, Donahue NM, Shrivastava MK, Weitkamp EA, Sage AM, Grieshop AP, Lane TE, Pierce JR, Pandis SN (2007) Science 315:1259-1262

16. Jayne JT, Leard DC, Zhang XF, Davidovits P, Smith KA, Kolb CE, Worsnop DR (2000) Aerosol Sci Technol 33:49-70

17. Lanz VA, Alfarra MR, Baltensperger U, Buchmann B, Hueglin C, Prévôt ASH (2007) Atmos Chem Phys 7:1503-1522

18. Zhang Q et al (2007) Geophys Res Lett 34:L13801. DOI 10.1029/ 2007GL029979

19. Lanz VA, Alfarra MR, Baltensperger U, Buchmann B, Hueglin C, Szidat S, Wehrli MN, Wacker L, Weimer S, Caseiro A, Puxbaum H, Prevot ASH (2007) Source attribution of submicron organic aerosols during wintertime inversions by advanced factor analysis of aerosol mass spectra. Environ Sci Technol (in press)

20. DeCarlo PF, Kimmel JR, Trimborn A, Northway MJ, Jayne JT, Aiken AC, Gonin M, Fuhrer K, Horvath T, Docherty KS, Worsnop DR, Jimenez JL (2006) Anal Chem 78:8281-8289

21. Szidat S, Prévôt ASH, Sanradewi J, Alfarra MR, Synal HA, Wacker L, Baltensperger U (2007) Geophys Res Lett 34:L05820. DOI 10.1029/2006GL028325

22. Szidat S, Jenk TM, Synal HA, Kalberer M, Wacker L, Hajdas I, Kasper-Giebl A, Baltensperger U (2006) J Geophys Res 111: D07206. DOI 10-1029/2005JD006590

23. Szidat S, Jenk TM, Gäggeler HW, Synal HA, Fisseha R, Baltensperger U, Kalberer M, Samburova V, Wacker L, Saurer M, Schwikowski M, Hajdas I (2004) Radiocarbon 46:475-484

24. Baltensperger U, Streit N, Weingartner E, Nyeki S, Prévôt ASH, van Dingenen R, Virkkula A, Putaud JP, Even A, ten Brink H, Blatter A, Neftel A, Gäggeler HW (2002) J Geophys Res 107 (D22):8193. DOI 10.1029/2001JD001292

25. Fuzzi S, Andreae MO, Huebert BJ, Kulmala M, Bond TC, Boy M, Doherty SJ, Guenther A, Kanakidou M, Kawamura K, Kerminen VM, Lohmann U, Russell LM, Pöschl U (2006) Atmos Chem Phys 6:2017-2038

26. Weber RJ, Sullivan AP, Peltier RE, Russell A, Yan B, Zheng M, de Gouw J, Warneke C, Brock C, Holloway JS, Atlas EL, Edgerton E (2007) J Geophys Res 112:D13302. DOI 10.1029/ 2007JD008408 